\title{
PENGARUH MEDIA PEMBELAJARAN DAN KECERDASAN GANDA TERHADAP HASIL BELAJAR TIK
}

\author{
Reni Astuti dan Mukhtar \\ PGSD FIP Unimed dan PPs Universitas Negeri Medan \\ reni.astuti@gmail.com
}

\begin{abstract}
Abstrak: Penelitian ini bertujuan untuk: mengetahui apakah hasil belajar TIK yang dibelajarkan dengan menggunakan media pembelajaran CD Multimedia Interaktif lebih tinggi dari pada yang dibelajarkan dengan menggunakan modul, mengetahui apakah hasil belajar TIK yang memiliki kecerdasan ganda visual spasial lebih tinggi dari pada yang memiliki kecerdasan ganda linguistik verbal, interaksi antara media pembelajaran dengan kecerdasan ganda dalam mempengaruhi hasil belajar TIK mahasiswa. Metode penelitian menggunakan metode quasi eksperimen dengan desain penelitian faktorial 2x2, sedangkan teknik analisis data menggunakan ANAVA dua jalur pada taraf signifikansi $\alpha=0.05$. Hasil penelitian diperoleh: hasil belajar TIK mahasiswa yang dibelajarkan dengan menggunakan media pembelajaran $\mathrm{CD}$ multimedia interaktif lebih tinggi dari pada yang dibelajarkan dengan modul; hasil belajar TIK mahasiswa yang memiliki kecerdasan ganda visual spasial lebih tinggi dibandingkan dengan yang memiliki kecerdasan ganda linguistik verbal; terdapat interaksi antara penggunaan media pembelajaran dengan kecerdasan ganda terhadap hasil belajar TIK mahasiswa.
\end{abstract}

Kata Kunci: pengaruh media pembelajaran CD Multimedia Interaktif dan modul, kecerdasan ganda, hasil belajar TIK

\begin{abstract}
This study aims to: determine whether the ICT learning outcomes that learned by using instructional media Interactive Multimedia $\mathrm{CD}$ is higher than that learned by using modules, determine whether the ICT learning outcomes that have multiple visual spatial intelligence higher than the multiple linguistic verbal intelligence, the interaction between media with multiple intelligences in influencing student learning outcomes ICT. Method using quasi-experimental research design with a $2 \times 2$ factorial study, while data analysis techniques using ANOVA two lanes at the significance level $\alpha=0: 05$. The results were obtained: ICT learning outcomes of students who learned with use of instructional media interactive multimedia $\mathrm{CD}$ is higher than that learned by the module; ICT learning outcomes of students who have multiple visual spatial intelligence higher than those that have multiple linguistic verbal intelligence; there is an interaction between media use multiple intelligences learning on learning outcomes of ICT students.
\end{abstract}

Keywords: effect of Interactive Multimedia $C D$ media and learning modules, multiple intelligences, learning outcomes ICT

\section{PENDAHULUAN}

Pendidikan Guru Sekolah Dasar (PGSD) adalah salah satu jenjang pendidikan yang terdapat di UNIMED. Jenjang pendidikan ini hadir sebagai upaya pemenuhan tuntutan pasar tentang kebutuhan guru SD yang profesional di Sumtera Utara. Untuk menjadi professional, banyak kompetensi yang harus dikuasai calon pendidik atau mahasiswa PGSD tersebut selama masa perkuliahan. Selain penguasaan terhadap bebagai dasar disiplin ilmu seperti ilmu sosial dan eksakta, sekarang ini mahasiswa PGSD atau calon guru SD harus menguasai beberapa kompetensi lain selain dasar disiplin ilmu tersebut. Penguasaan kompetensi ini terkait dengan lajunya pertumbuhan teknologi informasi dan komunikasi yaitu mata kuliah Teknologi Informasi dan Komunikasi (TIK). Tujuan mata kuliah ini adalah agar mahasiswa memiliki keterampilan dalam mengoperasionalkan komputer, memperkaya pengetahuannya dengan memanfaatkan segala TIK yang dikuasainya untuk digunakan dalam proses pembelajaran dan secara khusus dapat mengembangkan media pembelajaran berdasarkan ilmu yang diperolehnya dari mata kuliah ini. 
Sistem pembelajaran yang selama ini dilakukan adalah sistem pembelajaran konvensional (faculty teaching) yang terkenal dengan suasana instruksional dan dirasa kurang sesuai dengan dinamika perkembangan IPTEK. Lebih dari itu kewajiban proses pendidikan dituntut harus memasukkan nilai-nilai moral, budi pekerti luhur, kreatifitas, kemandirian dan kepemimpinan, yang sangat sulit dilakukan dalam sistem pembelajaran konvensional yang kurang fleksibel dalam mengakomodasi perkembangan materi kompetensi karena pendidik harus intensif menyesuaikan materi pelajaran dengan perkembangan teknologi terbaru. Perkembangan teknologi yang jauh lebih cepat dibanding dengan kemampuan pendidik dalam menyesuaikan materi kompetensi dengan perkembangan tersebut, akan menghasilkan lulusan yang kurang memiliki penguasaan teknologi yang terbaru.

Saat ini proses pembelajaran banyak dimudahkan dengan kehadiran media baru yaitu multimedia. Multimedia belakangan ini berkembang pesat seiiring dengan semakin pesatnya laju TIK. Multimedia mengkombinasikan berbagai media berupa audio, video, animasi, gambar, teks, dan lainlain. Kelebihan media ini adalah dapat membawa suasana belajar learning with effort menjadi learning with fun. Jadi proses pembelajaran yang menyenangkan, kreatif, tidak membosankan akan menjadi pilihan tepat bagi para pendidik. Multimedia dapat menyajikan materi yang lebih real dibandingkan dengan media cetak yang sifatnya verbal seperti buku teks, modul dan diktat. Jika kondisi pembelajaran berjalan dengan efektif dan dalam keadaan fun, maka revolusi cara belajar terjadi dan pembenahan pembelajaran dapat dilaksanakan secara berkelanjutan dengan memanfaatkan sumber daya yang ada.

Selain dari permasalahan tentang pengoptimalan media pembelajaran, dapat dilihat beberapa faktor lain yang mempengaruhi rendahnya penguasaan matakuliah TIK oleh mahasiswa. Faktor tersebut berasal dari dalam diri peserta didik yaitu kecerdasan yang mempengaruhi tingkat keberhasilan dalam proses belajar. Kecerdasan dalam diri manusia sesungguhnya tidak hanya satu tapi banyak yang disebut dengan kecerdasan ganda (multiple intelligence) yang mencakup kecerdasan linguistik verbal, kecerdasan logik matematik, kecerdasan visual spasial, kecerdasan musik, kecerdasan interpersonal, kecerdasan intrapersonal, kecerdasan kinestetik dan kecerdasan naturalis. Akan tetapi, tidak semua jenis kecerdasan tersebut ada dalam diri seseorang dan inilah yang menyebabkan perbedaan antara manusia yang satu dengan manusia lainnya.

Menurut Sabri (2007:108) menyatakan bahwa media pembelajaran merupakan alat yang digunakan sebagai perantara untuk menyampaikan pesan dan dapat merangsang pikiran, perasaan dan kemajuan audiend (peserta didik) sehingga dapat mendorong terjadinya proses belajar mengajar.

$$
\text { Hamalik (dalam Arsyad, 2007) }
$$

mengemukan bahwa pemakaian media pembelajaran dalam proses belajar mengajar dapat membangkitkan keinginan dan minat yang baru, membangkitkan motivasi dan ransangan kegiatan belajar dan bahkan membawa pengaruh-pengaruh psikologis terhadap peserta didik. Penggunaan media pembelajaran pada tahap orientasi pembelajaran akan sangat membantu keefektifan proses pembelajaran dan penyampaian pesan dan isi pelajaran pada saat itu. Selain itu juga dapat meningkatkan pemahaman, menyajikan data dengan menarik dan terpercaya, memudahkan penafsiran data dan memadatkan informasi.

Miarso (dalam Munadi, 2008:4) berpendapat bahwa media yang dirancang dengan baik dalam batas tertentu dapat merangsang timbulnya semacam dialog internal dalam diri peserta didik yang belajar. Dengan perkataan lain terjadi komunikasi antara peserta didik dengan media atau secara tidak langsung antara peserta didik dengan sumber pesan atau pendidik. Media berhasil membawakan pesan belajar bila kemudian terjadi perubahan kualitas dalam diri peserta didik. Kehadiran media akan membuat pendidik dapat meningkatkan minat peserta didik dalam proses belajar mengajar dan peserta didik dapat lebih cepat memahami dan mengerti terhadap materi yang disampaikan pendidik.

CD interaktif merupakan sebuah media yang menegaskan sebuah format multimedia dapat dikemas dalam sebuah CD dengan tujuan aplikasi Interaktif di dalamnya. CD ROM merupakan satu-satunya dari beberapa kemungkinan yang dapat menyatukan suara, video, teks, dan program dalam CD. Kemudian disebutkan bahwa CD interaktif adalah sebuah $\mathrm{CD}$ yang berisi menu-menu yang dapat diklik untuk menampilkan sebuah informasi tertentu. Sistem Interaktif yang dipakai $C D$ interactif sama persis dengan sistem navigasi pada internet, hanya yang berbeda di sini adalah 
media yang dipakai keduanya. CD Interaktif memakai media off line berupa CD sementara Internet memakai media online.

Arsyad (2007:170) menyatakan bahwa secara sederhana multimedia diartikan sebagai "lebih dari satu media" yang dapat berupa kombinasi antara teks, grafik dan animasi, suara, dan video. Penggabungan ini merupakan suatu kesatuan yang secara bersama-sama menampilkan informasi, pesan, atau isi pelajaran.

Santyasa (2009) mendefinisikan modul sebagai suatu cara pengorganisasian materi pelajaran yang memperhatikan fungsi pendidikan. Strategi pengorganisasian materi pembelajaran mengandung squencing yang mengacu pada pembuatan urutan penyajian materi pelajaran, dan synthesizing yang mengacu pada upaya untuk menunjukkan kepada pebelajar keterkaitan antara fakta, konsep, prosedur dan prinsip yang terkandung dalam materi pembelajaran. Untuk merancang materi pembelajaran, terdapat lima kategori kapabilitas yang dapat dipelajari oleh pebelajar, yaitu informasi verbal, keterampilan intelektual, strategi kognitif, sikap, dan keterampilan motorik.

Modul yaitu suatu paket progaram yang disusun dalam bentuk satuan tertentu dan didesain sedemikian rupa guna kepentingan belajar siswa. Satu paket modul biasanya memiliki komponen petunjuk guru, lembaran kegiatan siswa, lembaran kerja siswa, kunci lembaran kerja lembaran tes, dan kunci lembaran tes.

Munandar (1999) menyatakan bahwa kecerdasan (inteligensi) ditentukan dari bakat bawaan berdasarkan gen yang diturunkan dari orang tuanya) maupun dari faktor lingkungannya termasuk semua pengalaman pendidikan yang pernah diperoleh seseorang. Secara umum kecerdasan dapat dirumuskan sebagai berikut : (1) kemampuan untuk berfikir abstrak, (2) kemampuan untuk menangkap hubungan - hubungan dan untuk belajar, dan (3) kemampuan untuk menyesuaikan diri terhadap situasi-situasi baru. Feldam dalam Uno (2008:59) menjelaskan tentang pengertian kecerdasan sebagai kemampuan memahami dunia, berpikir secara rasional dan menggunakan sumber-sumber secara efektif pada saat dihadapkan dengan tantangan, sedangkan Henmon dalam Uno (2008:60) mendefinisikan kecerdasan sebagai daya atau kemampuan untuk memahami.

Gardner (dalam Campbell, 1996:12) menyatakan bahwa kecerdasan intelektual hanyalah salah satu dari 8 kecerdasan yang dimiliki seseorang. Teori dari penelitian Gardner ini terus mendapatkan sorotan mengingat selama ini pendidikan formal hanya mengukur prestasi peserta didik hanya pada kecerdasan logika dan linguistik saja. Gardner kemudian mengembangkan teori tentang kecerdasan ganda dengan mendasarkan kerja para Jean Piaget. Gardner memiliki pandangan bahwa kecerdasan bukanlah sesuatu bersifat tetap dan tidak hanya satu dengan kadar yang berbeda-beda. Jadi kecerdasan yang dimiliki manusia itu sesungguhnya ganda, dan atau banyak jenisnya. Penelitian Gardner menggeser paradigma lama yang menyatakan bahwa "kecerdasan adalah kapasitas yang sudah pasti", menjadi suatu kapasitas yang berkesinambungan, dapat dikembangkan seumur hidup, dan tak terbatas. Gardner dalam Campbell (1996:15) juga menyatakan bahwa pada dasarnya setiap individu itu semua berbeda dengan kombinasi kecerdasan yang dimilikinya. Bila individu tersebut mampu mengenalinya, maka individu tersebut mempunyai setidaknya sebuah kesempatan yang bagus untuk mengatasi berbagai masalah yang dihadapi di dunia (Lucy, 2009).

Gardner (dalam Campbell, 1996:30) berpendapat bahwa sebenarnya kecerdasan manusia itu banyak atau ganda. Jenis kecerdasan ganda yang terdapat dalam diri seseorang adalah : (1) kecerdasan linguistik verbal, (2) kecerdasan matematis logis, (3) kecerdasan visual spasial, (4) kecerdasan kinestetik, (5) kecerdasan musik, (6) kecerdasan interpersonal, (7) kecerdasan intrapersonal, dan (8) kecerdasan naturalis.

Lwin dkk (2008: 79) mendefinisikan kecerdasan visual spasial adalah kecerdasan yang dimiliki oleh anak yang memiliki kemampuan untuk melihat dengan tepat gambaran-gambaran visual di sekitar mereka dengan memperhatikan rincian kecil yang kebanyakan orang tidak memperhatikannya atau dengan kata lain mereka memilki kekuatan persepsi yang besar. Kecerdasan visual-spasial menurut Prasetyo dkk (2009: 57) merupakan kapasitas untuk mengenali dan melakukan penggambaran atas objek atau pola yang diterima otak. Seseorang yang memiliki kecerdasan ini mempunyai kapasitas mengelola gambar, bentuk dan ruang tiga dimensi dengan aktivitas utama mengenali bentuk, warna dan ruang serta menciptakan gambar secara mental maupun realitis. Kecerdasan ini adalah kecerdasan gambar dan visualisasi, kemampuan 
untuk mengindera dunia secara akurat dan menciptakan kembali atau mengubah aspekaspek dunia tersebut (Hoerr, 2007). Kecerdasan ini melibatkan kemampuan untuk memvisualisasikan gambar di dalam kepala seseorang dan menciptakannya dalam bentuk dua atau tiga dimensi. Peserta didik yang memilki kecerdasan visual ini biasanya memiliki kemampuan untuk menterjemahkan gambaran dalam pikiran mereka ke dalam bidang fisik melalui penggambaran, pelukisan, pemahatan, pembangunan atau pembentukan.

Jasmine (2007:16) menyatakan bahwa kecerdasan linguistik banyak disebut pendidik sebagai kecerdasan verbal yang berbeda dengan kecerdasan lainnya sebab seseorang yang memiliki kecerdasan ini biasanya memiliki kemampuan berkata-kata dan bertutur dengan tingkatan/level yang berbeda-beda. Prasetyo dkk (2009:43) mengemukakan bahwa kecerdasan linguistik merupakan kapasitas menggunakan bahasa untuk menyampaikan pikiran dan memahami perkataan orang lain, baik secara lisan maupun tertulis. Kecerdasan linguistik adalah kemampuan menggunakan kata-kata secara efektif (Armstrong, 2005) atau hal-hal yang berhubungan dengan kepekaan pada makna dan susunan kata (Hoerr, 2007). Membaca dan menulis yang menjadi tolok ukur tes bakat tradisional merupakan contoh dari kecerdasan ini. Kecerdasan linguistik seringkali menjelma dalam kata-kata baik tulisan maupun lisan.

Penelitian ini bertujuan untuk mengetahui: (1) Hasil belajar TIK mahasiswa yang diajarkan dengan media pembelajaran $\mathrm{CD}$ multimedia interaktif lebih tinggi dibandingkan hasil belajar TIK mahasiswa yang diajarkan dengan media pembelajaran modul; (2) Hasil belajar TIK mahasiswa yang memiliki kecerdasan visual spasial lebih tinggi dibandingkan dengan mahasiswa yang memiliki kecerdasan linguistik verbal; (3) Interaksi antara media pembelajaran dan kecerdasan ganda dalam mempengaruhi hasil belajar TIK.

\section{METODE PENELITIAN}

Penelitian ini dilaksanakan di Fakultas Ilmu Pendidikan Jurusan PGSD semester ganjil. Populasi penelitian adalah seluruh mahasiswa PGSD yang mengikuti matakuliah TIK. Syarat kelayakan populasi dapat digunakan menjadi sampel adalah harus lulus matakuliah Aplikasi Komputer pada semester sebelumnya dan memiliki karakteristik yang sama setiap kelasnya. Kompetensi awal yang harus dimiliki mahasiswa agar dapat mengikuti matakuliah TIK adalah telah mengetahui dengan baik pengoperasionalan komputer secara dasar dengan cara mampu menggunakan aplikasi windows, aplikasi office dan dapat menjalankan perintah dasar pada pengoperasionalan sebuah komputer. Mahasiswa harus memiliki nilai ratarata yang sama baik dari kelas reguler maupun ekstensi yang terlihat pada hasil pengujian pretest mahasiswa untuk melihat kemampuan menggunakan komputernya. Sampel dipilih dengan cluster random sampling (sampel acak kelompok), yang dari 6 kelas dipilih 4 kelas sebagai eksperimen acak.

Penelitian ini menggunakan metode eksperimen dengan rancangan quasi eksperimen desain faktorial $2 \times 2$ dengan desain ini akan dibandingkan pengaruh media pembelajaran CD multimedia interaktif dan media pembelajaran modul. Media pembelajaran CD multimedia interaktif dan media pembelajaran modul diperlakukan kepada kelompok eksperimen mahasiswa dengan kecerdasan ganda yang berbeda. Penelitian ini terdiri dari variabel bebas dan terikat. Variabel bebas terdiri dari media pembelajaran dan kecerdasan ganda. Media pembelajaran yang dipilih adalah media pembelajaran $\mathrm{CD}$ multimedia Interaktif dan media pembelajaran modul. Sedangkan kecerdasan ganda yang dipilih adalah kecerdasan visual spasial dan kecerdasan linguistik verbal, sedangkan variabel terikatnya adalah hasil belajar matakuliah TIK.

Teknik pengumpulan data yang digunakan dalam penelitian ini menggunakan tes dan non tes. Untuk memperoleh data mengenai hasil belajar TIK yang diperlukan dalam penelitian ini, peneliti menggunakan tes hasil belajar, sedangkan untuk kecerdasan ganda teknik pengumpulan data yang digunakan adalah dengan kuesioner atau non tes melalui ahli psikologi.

Teknik analisis data yang digunakan adalah teknik statistik inferensial dan deskriptif. Teknik statistik deskriptif digunakan untuk mendeskripsikan data, antara lain : nilai rata-rata (mean), median, modus, standar deviasi, dan kecenderungan data. Teknik statistik inferensial digunakan untuk menguji hipotesis penelitian, dimana teknik inferensial yang digunakan adalah teknik analisis varians dua jalur dengan taraf signifikan 0,05 . Sebelum teknik ini digunakan perlu dilakukan uji persyaratan. Uji persyaratan yang dilakukan adalah uji normalitas menggunakan uji Lilliefors (Sudjana, 2002:466) dan uji 
homogenitas menggunakan uji Barlett dan uji Fisher (uji F) (Sudjana, 2002:261). Bila terdapat interaksi antara variabel maka analisis dilanjutkan dengan uji Scheffe bila banyak data dalam setiap kelompok dan baris berbeda dan uji Tuckey bila banyak data dalam setiap kolom dan baris sama.

\section{HASIL DAN PEMBAHASAN}

Tabel 1. Rangkuman Data Hasil Perhitungan Analisis Deskriptif

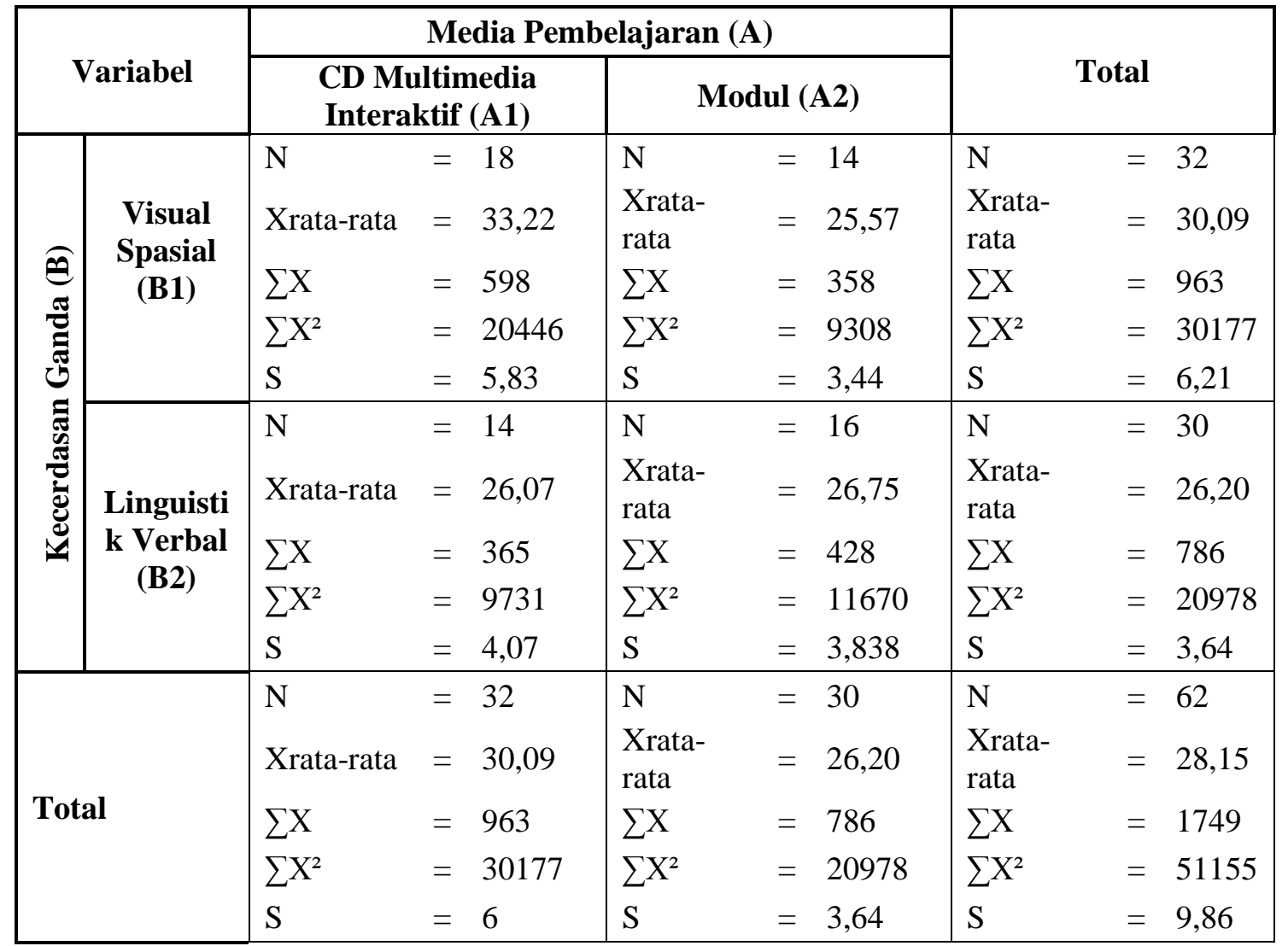

bawah ini.

Secara keseluruhan hasil Anava untuk pengujian hipotesis dapat dilihat pada Tabel 2 di

Tabel 2. Ringkasan Perhitungan ANAVA Faktorial 2 x 2

\begin{tabular}{|l|c|c|c|c|c|}
\hline \multicolumn{1}{|c|}{ Sumber Variasi } & $\mathrm{Dk}$ & $\mathrm{JK}$ & $\mathrm{RJK}$ & $\mathrm{F}_{\text {hit }}$ & $\mathrm{F}_{\text {tabel }(\alpha=0.05)}$ \\
\hline Antar Kelompok & 3 & 647,806 & 215,935 & & \\
Strategi Pembelajaran & 1 & 234,755 & 234,755 & 11.652 & 4,00 \\
Kecerdasan Ganda & 1 & 234,755 & 234,755 & 11,652 & 4,00 \\
Interaksi & 1 & 178,295 & 178,295 & 8,85 & 4,00 \\
Galat (Dalam Kelompok) & 58 & 1168,468 & 20,146 & & \\
\hline Total & & & & & \\
\hline
\end{tabular}

Perbedaan Hasil Belajar TIK Mahasiswa Yang Dibelajarkan dengan Media Pembelajaran CD Multimedia Interaktif dan Modul.
Hasil

Untuk keperluan pengujian hipotesis dengan menggunakan tehnik analisis varian dua jalur (ANAVA) faktorial $2 \times 2$ dan uji lanjut Scheffe diperlukan harga rata-rata tiap kelompok, berikut ini akan disajikan data hasil belajar TIK mahasiswa pada Tabel 1. dengan menggunakan analisis deskriptif. 
Ho = Hasil Belajar TIK Mahasiswa Yang Dibelajarkan Dengan Menggunakan Media Pembelajaran CD Multimedia Interaktif Sama Dengan Hasil Belajar TIK Mahasiswa Yang Dibelajarkan Dengan Media Pembelajaran Modul

$\mathrm{Ha}=$ Hasil Belajar TIK Mahasiswa Yang Dibelajarkan Dengan Menggunakan Media Pembelajaran CD Multimedia Interaktif Lebih Tinggi Dengan Hasil Belajar TIK Mahasiswa Yang Dibelajarkan Dengan Media Pembelajaran Modul

Berdasarkan hasil pengujian hipotesis pada tabel 2 di atas, maka diperoleh hasil perhitungan data media pembelajaran, dimana $F_{\text {hitung }}=11,652$ sementara nilai kritik $F_{\text {tabel }}$ dengan $\mathrm{dk}_{(1,61)}$ dan $\alpha=0.05$ adalah sebesar 4,00 . Hasil ini menunjukkan bahwa $F_{\text {hitung }}=11,652>$ $\mathrm{F}_{\text {tabel }}=4,00$ sehingga Hipotesis $\mathrm{Nol}(\mathrm{Ho})$ ditolak. Dengan demikian dapat disimpulkan bahwa hasil belajar TIK mahasiswa yang dibelajarkan dengan media pembelajaran $\mathrm{CD}$ multimedia interaktif lebih tinggi dari hasil belajar mahasiswa yang dibelajarkan dengan menggunakan media pembelajaran modul.

Perbedaan Hasil Belajar TIK Antara Mahasiswa Yang Memiliki Kecerdasan Ganda Visual Spasial dan Kecerdasan Ganda Linguistik Verbal. Perbedaan hasil belajar TIK mahasiswa yang memiliki kecerdasan ganda visual spasial dan kecerdasan ganda linguistik verbal dilakukan dengan analisis varians (ANAVA).

Pengujian dilakukan terhadap hipotesis statistik yang dirumuskan sebagai berikut :

Ho : $\mu \mathrm{B} 1 \leq \mu \mathrm{B} 2$; $\mathrm{Ha}: \mu \mathrm{B} 1>\mu \mathrm{B} 2$

Pernyataan Hipotesis tersebut adalah :

Ho = Hasil Belajar TIK Mahasiswa Yang Memiliki Kecerdasan Ganda Visual Spasial Sama Dengan Hasil Belajar TIK Mahasiswa Yang Memiliki Kecerdasan Ganda Linguistik Verbal

$\mathrm{Ha}=$ Hasil Belajar TIK Mahasiswa Yang Memiliki Kecerdasan Ganda Visual Spasial Lebih Tinggi Dari Hasil Belajar TIK Mahasiswa Yang Memiliki Kecerdasan Ganda Linguistik Verbal

Berdasarkan hasil pengujian hipotesis pada Tabel 2 di atas diperoleh hasil perhitungan data kecerdasan ganda, dimana $F_{\text {hitung }}=11,652$ dan nilai kritik $\mathrm{F}_{\text {tabel }}$ dengan $\mathrm{dk}{ }_{(1,61)}$ dan $\alpha=$
0.05 adalah 4,00. Hasil ini menunjukkan bahwa $F_{\text {hitung }}=11,652>F_{\text {tabel. }}=4,00$ sehingga Hipotesis Nol (Ho) ditolak. Dengan demikian dapat disimpulkan bahwa hasil belajar TIK mahasiswa yang memiliki kecerdasan ganda visual spasial memperoleh hasil belajar TIK yang lebih tinggi dari pada mahasiswa yang memiliki kecerdasan ganda linguistik verbal.

Interaksi Antara Media Pembelajaran dan Kecerdasan Ganda Dalam Mempengaruhi Hasil Belajar TIK Mahasiswa.

Pengujian dilakukan terhadap hipotesis statistik yang dirumuskan sebagai berikut :

Ho : $\mathrm{A}>\langle\mathrm{B}=0 ; \mathrm{Ha}: \mathrm{A}><\mathrm{B} \neq 0$

Pernyataan Hipotesis tersebut adalah :

Ho = Tidak Terdapat Interaksi Antara Media Pembelajaran dengan Kecerdasan Ganda Dalam Mempengaruhi Hasil Belajar TIK Mahasiswa.

$\mathrm{Ha}=$ Terdapat Interaksi Antara Media Pembelajaran dengan Kecerdasan Ganda Dalam Mempengaruhi Hasil Belajar TIK Mahasiswa.

Berdasarkan hasil pengujian hipotesis di atas diperoleh perhitungan interaksi media pembelajaran dengan kecerdasan ganda, dimana $\mathrm{F}_{\text {hitung }}=8,85$ dan nilai kritik $\mathrm{F}_{\text {tabel }}$ dengan $\mathrm{dk}_{(1,61)}$ dan $\alpha=0.05 \%$ adalah 4,00. Hasil ini menunjukkan bahwa $F_{\text {hitung }}=8,85>\mathrm{F}_{\text {tabel. }}=4,00$ sehingga Hipotesis Nol (Ho) ditolak. Dengan demikian dapat disimpulkan bahwa terdapat interaksi antara media pembelajaran dan kecerdasan ganda dalam mempengaruhi hasil belajar TIK mahasiswa teruji kebenarannya.

Karena terdapat interaksi antara media pembelajaran dan kecerdasan ganda dalam mempengaruhi hasil belajar TIK, maka perlu dilakukan uji lanjutan (post hoc test), untuk mengetahui rata-rata hasil belajar sampel mana yang berbeda. Uji lanjut yang digunakan untuk melihat perbedaan rata-rata hasil belajar tersebut adalah uji Schefee. Uji lanjut ini digunakan untuk menguji data yang tidak homogen. Dalam penelitian ini terdapat 5 hipotesis statistik yang menunjukan perbedaan rata-rata hasil belajar, jadi uji lanjut yang digunakan adalah uji Schefee. Bentuk perbedaan interaksi antara media pembelajaran dan kecerdasan ganda dalam mempengaruhi hasil belajar TIK tersebut dapat dilihat dalam ringkasan hasil uji Scheffe dapat dilihat pada Tabel 3 berikut: 
Tabel 3. Ringkasan Hasil Perhitungan Uji Scheffe

\begin{tabular}{|l|c|c|c|c|}
\hline \multicolumn{2}{|c|}{ Hipotesis Statistik } & $F_{\text {hitung }}$ & $\begin{array}{c}F_{\text {tabel } \alpha=} \\
0,05\end{array}$ & Keterangan \\
\hline Ho $: \mu \mathrm{A} 1 \mathrm{~B} 1=\mu \mathrm{A} 2 \mathrm{~B} 1$ & Ha $: \mu \mathrm{A} 1 \mathrm{~B} 1>\mu \mathrm{A} 2 \mathrm{~B} 1$ & 4.783 & 2,76 & Signifikan \\
\hline Ho $: \mu \mathrm{A} 1 \mathrm{~B} 1=\mu \mathrm{A} 2 \mathrm{~B} 2$ & Ha $: \mu \mathrm{A} 1 \mathrm{~B} 1>\mu \mathrm{A} 2 \mathrm{~B} 2$ & 4.196 & 2,76 & Signifikan \\
\hline Ho $: \mu \mathrm{A} 1 \mathrm{~B} 1=\mu \mathrm{A} 1 \mathrm{~B} 2$ & Ha $: \mu \mathrm{A} 1 \mathrm{~B} 1>\mu \mathrm{A} 1 \mathrm{~B} 2$ & 4.470 & 2,76 & Signifikan \\
\hline Ho $: \mu \mathrm{A} 2 \mathrm{~B} 1=\mu \mathrm{A} 2 \mathrm{~B} 2$ & Ha $: \mu \mathrm{A} 2 \mathrm{~B} 1>\mu \mathrm{A} 2 \mathrm{~B} 2$ & 0.717 & 2,76 & tidak signifikan \\
\hline Ho $: \mu \mathrm{A} 1 \mathrm{~B} 2=\mu \mathrm{A} 2 \mathrm{~B} 2$ & Ha $: \mu \mathrm{A} 1 \mathrm{~B} 2>\mu \mathrm{A} 2 \mathrm{~B} 2$ & 0.413 & 2,76 & tidak signifikan \\
\hline Ho $: \mu \mathrm{A} 2 \mathrm{~B} 1=\mu \mathrm{A} 1 \mathrm{~B} 2$ & Ha $: \mu \mathrm{A} 2 \mathrm{~B} 1>\mu \mathrm{A} 1 \mathrm{~B} 2$ & 0.294 & 2,76 & tidak signifikan \\
\hline
\end{tabular}

Kriteria penerimaan jika $: F_{\text {hitung }}>F_{\text {tabel, }}$ maka teruji secara signifikan. Berdasarkan hasil uji Scheffe pada Tabel 3 di atas dapat dilihat bahwa terdapat 6 (enam) pasang hipotesis statistik, yakni :

a. Dari hasil perhitungan dengan menggunakan uji Scheffe pada tabel di atas menunjukkan bahwa $F_{\text {hitung }}=4,78>F_{\text {tabel }}=2,76$, sehingga memberikan keputusan menolak Ho. Dengan demikian, hipotesis penelitian yang menyatakan bahwa hasil belajar TIK mahasiswa jika dibelajarkan dengan menggunakan media pembelajaran $\mathrm{CD}$ multimedia interaktif dengan kecerdasan ganda visual spasial lebih tinggi dibandingkan dengan hasil belajar mahasiswa jika dibelajarkan dengan media pembelajaran modul untuk mahasiswa yang memiliki kecerdasan ganda visual spasial teruji kebenarannya.

b. Dari hasil perhitungan dengan menggunakan uji Scheffe pada Tabel di atas menunjukkan $\mathrm{F}_{\text {hitung }}=4.196<\mathrm{F}_{\text {tabel }}=2,76$, sehingga memberikan keputusan menolak Ho. Dengan demikian, hipotesis penelitian yang menyatakan bahwa hasil belajar TIK mahasiswa jika dibelajarkan dengan menggunakan media pembelajaran $\mathrm{CD}$ multimedia interaktif dengan kecerdasan ganda visual spasial lebih tinggi dibandingkan dengan hasil belajar mahasiswa jika dibelajarkan dengan menggunakan media pembelajaran modul dengan kecerdasan ganda linguistik verbal teruji kebenarannya.

c. Dari hasil perhitungan dengan menggunakan uji Scheffe pada Tabel di atas menunjukkan $\mathrm{F}_{\text {hitung }}=4.470>\mathrm{F}_{\text {tabel }}=2,76$, sehingga memberikan keputusan menolak Ho. Dengan demikian, hipotesis penelitian yang menyatakan bahwa hasil belajar TIK mahasiswa jika dibelajarkan dengan menggunakan media pembelajaran $\mathrm{CD}$ multimedia dengan kecerdasan ganda visual spasial lebih tinggi dibandingkan dengan hasil belajar mahasiswa jika dibelajarkan dengan media pembelajaran CD multimedia interaktif dengan kecerdasan ganda linguistik verbal teruji kebenarannya.

d. Dari hasil perhitungan dengan menggunakan uji Scheffe pada Tabel di atas menunjukkan $\mathrm{F}_{\text {hitung }}=0.717>\mathrm{F}_{\text {tabel }}=2,76$, sehingga memberikan keputusan menerima Ho. Dengan demikian, hipotesis penelitian yang menyatakan bahwa hasil belajar TIK mahasiswa jika dibelajarkan dengan menggunakan media pembelajaran modul dengan kecerdasan ganda visual spasial lebih tinggi dari pada hasil belajar TIK mahasiswa jika dibelajarkan dengan menggunakan media pembelajaran modul dengan kecerdasan linguistik verbal tidak teruji kebenarannya. Dengan demikian tidak terdapat perbedaan antara hasil belajar TIK mahasiswa yang dibelajarkan dengan media pembelajaran modul baik untuk mahasiswa yang memiliki kecerdasan ganda visual spasial maupun mahasiswa yang memilki kecerdasan ganda linguistik verbal.

e. Dari hasil perhitungan dengan menggunakan uji Scheffe pada Tabel di atas menunjukkan $\mathrm{F}_{\text {hitung }}=0.413>\mathrm{F}_{\text {tabel }}=2,76$, sehingga memberikan keputusan menerima Ho. Dengan demikian, hipotesis penelitian yang menyatakan bahwa Hasil belajar TIK mahasiswa jika dibelajarkan dengan menggunakan media pembelajaran $\mathrm{CD}$ multimedia interaktif dengan kecerdasan ganda linguistik verbal lebih tinggi dibandingkan dengan hasil belajar mahasiswa jika dibelajarkan dengan menggunakan media pembelajaran modul dengan kecerdasan ganda linguistik verbal tidak teruji kebenarannya. Dengan demikian tidak terdapat perbedaan antara hasil belajar TIK mahasiswa yang dibelajarkan dengan media pembelajaran $\mathrm{CD}$ multimedia 
interaktif dan modul untuk mahasiswa yang memiliki kecerdasan ganda linguistik verbal.

Selanjutnya adanya interaksi antara variabel media pembelajaran dan kecerdasan ganda terhadap hasil belajar TIK mahasiswa, maka perlu diberikan gambaran grafik estimasi yang menunjukkan adanya interaksi tersebut.

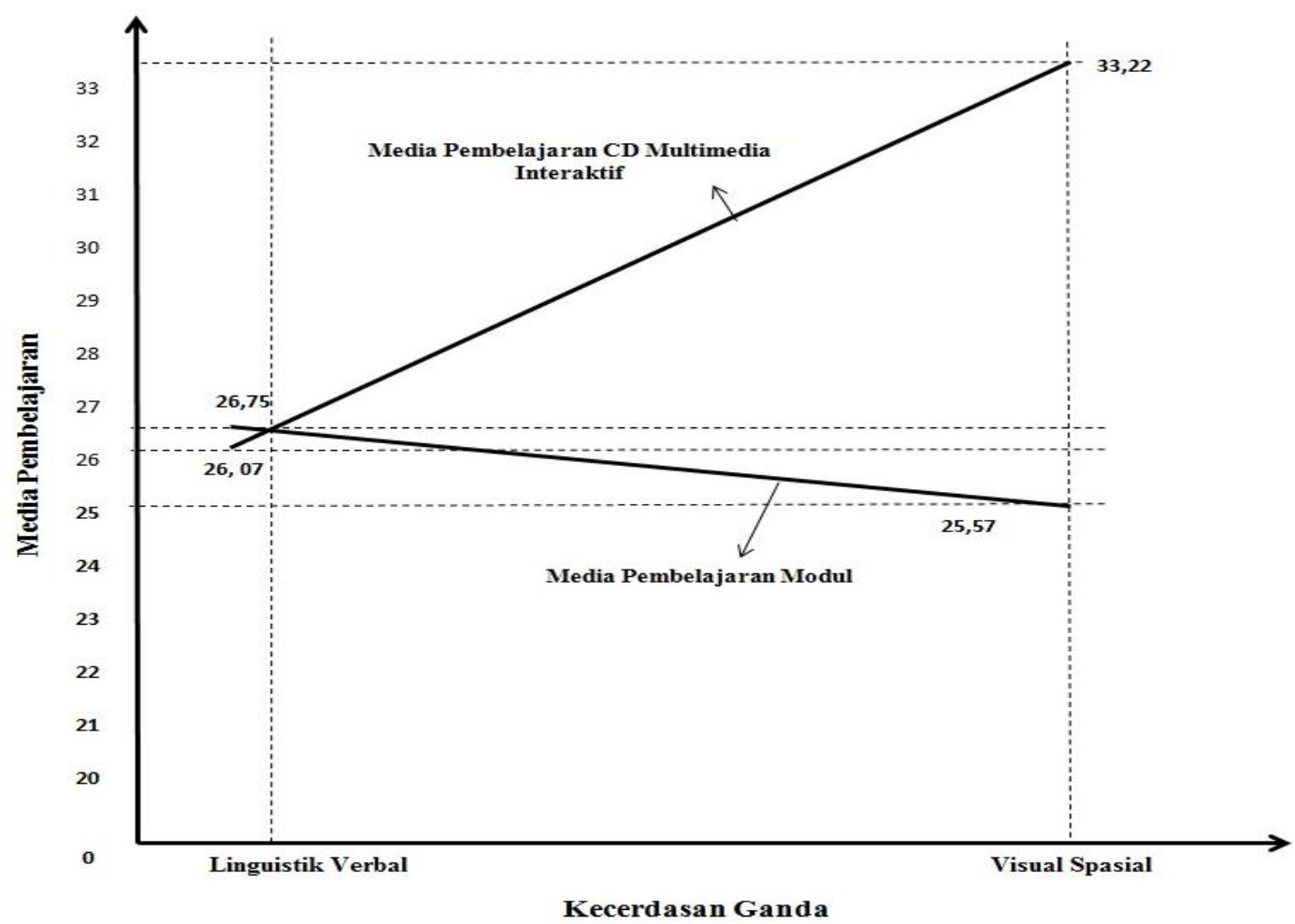

Gambar 1. Interaksi Antara Media Pembelajaran dan Kecerdasan Ganda Terhadap Hasil Belajar TIK Mahasiswa

\section{Pembahasan}

Hasil Belajar TIK Mahasiswa Yang Dibelajarkan Dengan Media Pembelajaran CD Multimedia Interaktif Lebih Tinggi Dibandingkan Dengan Hasil Belajar Mahasiswa Yang Dibelajarkan Dengan Menggunakan Media Pembelajaran Modul. Hasil penelitian ini telah menunjukkan bahwa hasil belajar TIK mahasiswa yang dibelajarkan dengan menggunakan media pembelajaran $\mathrm{CD}$ multimedia interaktif lebih tinggi dibandingkan dengan hasil belajar TIK mahasiswa media pembelajaran modul. Ini menunjukkan bahwa media pembelajaran $\mathrm{CD}$ multimedia interaktif dapat meningkatkan hasil belajar TIK mahasiswa secara keseluruhan baik untuk kelompok mahasiswa dengan kecerdasan ganda visual spasial maupun kecerdasan ganda linguistik verbal.

Proses belajar mengajar pada hakikatnya adalah proses komunikasi yaitu proses penyampaian pesan dari sumber pesan melalui saluran/media tertentu ke penerima pesan. Pesan yang akan dikomunikasikan adalah ajaran atau didikan yang terdapat dalam kurikulum. Dalam proses pembelajaran, sumber pesan tersebut biasanya guru/pendidik atau dosen. Sedangkan salurannya adalah media pembelajaran dan penerima pesannya adalah siswa atau mahasiswa. Menurut Latuheru dalam Widodo (2008 : 30) memberikan pendapat bahwa media sebagai semua bentuk perantara yang digunakan oleh manusia untuk menyampaikan atau menyebarkan ide, gagasan, atau pendapat sehingga ide, gagasan atau pendapat yang dikemukakan itu sampai pada penerima yang dituju.

Matakuliah TIK adalah materi kuliah yang mempelajari tentang penggunaan, pemanfaatan dan pengintegrasian perangkat teknologi dan informasi yang berkembang. Hasil akhir dari pemahaman materi matakuliah ini adalah mahasiswa mampu menggunakan dan memanfaatkan perangkat tersebut dalam dunia bisnis niaga, pembelajaran, dan hiburan. Khusus mahasiswa PGSD, pemahaman mendalam tentang matakuliah TIK diharapkan mampu menggunakan, memanfaatkan dan mengintegrasikan perangkat teknologi informasi dalam proses pembelajaran. 
Mahasiswa PGSD adalah mahasiswa yang outpunya diharapkan mampu menjadi pendidik untuk jenjang pendidikan sekolah dasar. Dengan adanya matakuliah ini mahsiswa diharapkan mampu memanfaatkan perangkat teknologi dan informasi dalam menyampaikan informasi kepeserta didik dengan kedudukan sebagai guru sekolah dasar kelak.

Salah satu yang mendukung pengembangan kurikulum berbasis kompetensi di perguruan tinggi adalah dengan adanya media pembelajaran multimedia. Hal ini sejalan dengan pendapat Najjar dalam Widodo (2008), multimedia adalah penyampaian informasi dengan menggunakan gabungan dari teks, gambar, suara, video dan animasi. Pembelajaran dengan menggunakan multimedia dapat membuat proses belajar peserta didik lebih baik.

Mahasiswa Yang Memiliki Kecerdasan Ganda Visual Spasial Memperoleh Hasil Belajar TIK Lebih Tinggi dari Pada Mahasiswa yang Memiliki Kecerdasan Ganda Linguistik Verbal. Hasil penelitian ini telah menunjukkan bahwa mahasiswa yang memiliki kecerdasan ganda visual spasial memperoleh nilai rata-rata hasil belajar TIK yang lebih baik dibandingkan dengan mahasiswa yang memiliki kecerdasan ganda linguistik verbal.

Kecerdasan telah ada saat manusia dilahirkan yang meliputi kecerdasan bahasa, matematik dan visual spasial. Gardner (1998) membuat kajian tentang teori kognitif tentang suatu model kecerdasan yang multidemensi. Menurut Gardner, kecerdasan adalah kapasitas untuk menyelesaikan masalah-masalah dan membuat cara penyelesaiannya dalam konteks yang beragam dan wajar. Gardner mengemukakan bahwa manusia pada umumnya memiliki delapan kecerdasan yaitu linguistic verbal, logika matematis, visual spasial, kinestetik, music, interpersonal, intrapersonal, dan naturalis. Manfaat terbesar dari mengetahui kecerdasan yang dimiliki adalah dapat memaksimalkan seluruh potensi yang ada dan berguna dalam menjalani dan melakukan aktivitas sehari-hari.

Integrasi warna, pola, desain, garis dan ruang yang terdapat dalam aplikasi sebuah komputer secara tidak langsung akan memotivasi penggunanya untuk lebih mendalami perangkat tersebut. Seluruh elemen terdapat didalam komputer merupakan elemen yang terdapat pada kecerdasan ganda visual spasial. Walau tidak sepenuhnya hanya unsur visual spasial saja yang menjadi bagian utuh matakuliah komputer ini. Ada unsur pendukung lainnnya yang cukup berperan dalam mendalami matakuliah komputer ini. Unsur tersebut berbeda kadarnya antara individu yang satu dengan individu yang lainnya. Unsur tersebut terdapat didalam teori kecerdasan ganda yang dikemukakan Gardner. Terdapat unsur verbalitas dalam memahami setiap petunjuk pengoperasian suatu perangkat komputer. Pemahaman yang baik atas unsur verbal dan auditori akan mampu menghasilkan pembelajaran yang optimal.

Hal ini sesuai dengan Asumsi yang mendasari teori pemrosesan informasi mengenai pembelajaran merupakan faktor yang sangat penting dalam perkembangan. Perkembangan merupakan hasil kumulatif dari pembelajaran. Menurut Gagne bahwa dalam pembelajaran terjadi proses penerimaan informasi, untuk kemudian diolah sehingga menghasilkan keluaran dalam bentuk hasil belajar. Dalam pemrosesan informasi terjadi adanya interaksi antara kondisi-kondisi internal dan kondisi-kondisi eksternal individu. Kondisi internal yaitu keadaan dalam diri individu yang diperlukan untuk mencapai hasil belajar dan proses kognitif yang terjadi dalam individu. Sedangkan kondisi eksternal adalah rangsangan dari lingkungan yang mempengaruhi individu dalam proses pembelajaran.

Menurut Gagne tahapan proses pembelajaran meliputi delapan fase yaitu, (1) motivasi; (2) pemahaman; (3) pemerolehan; (4) penyimpanan; (5) ingatan kembali; (6) generalisasi; (7) perlakuan dan (8) umpan balik. Teori pemrosesan informasi adalah teori kognitif tentang belajar yang menjelaskan pemrosesan, penyimpanan, dan pemanggilan kembali pengetahuan dari otak (Slavin, 2000: 175). Teori ini menjelaskan bagaimana seseorang memperoleh sejumlah informasi dan dapat diingat dalam waktu yang cukup lama. Oleh karena itu perlu menerapkan suatu strategi belajar tertentu yang dapat memudahkan semua informasi diproses di dalam otak melalui beberapa indera.

Terdapat Interaksi Antara Media Pembelajaran dan Kecerdasan Ganda Dalam Mempengaruhi Hasil Belajar TIK. Media cukup penting dalam proses belajar mengajar karena media akan dapat digunakan untuk mendukung aktivitas pemebelajaran. Kehadiran media dalam pembelajaran akan meningkatkan perhatian peserta didik pada content yang sedang disajikan sehingga pengalaman/kesan/memori akan lebih banyak 
terekam. Media membantu peserta didik mengingat kembali apa yang telah dipelajari sebelumnya. Media dapat menghadirkan new content (video, movie, dll). Media dapat mendukung pembelajaran melalui elaborasi visual.

\section{PENUTUP}

\section{Simpulan}

Kesimpulan hasil penelitian ini adalah sebagai berikut:

1. Hasil belajar TIK mahasiswa yang dibelajarkan dengan menggunakan media pembelajaran $\mathrm{CD}$ Multimedia Interaktif lebih baik dibandingkan dengan media pembelajaran Modul. Dengan demikian mahasiswa yang dibelajarkan dengan menggunakan media pembelajaran $\mathrm{CD}$ Multimedia Interaktif lebih baik dibandingkan dengan hasil belajar mahasiswa yang diajarkan dengan media pembelajaran Modul

2. Hasil belajar mahasiswa yang memiliki kecerdasan ganda visual spasial lebih baik dibandingkan dengan hasil belajar mahasiswa yang memiliki kecerdasan ganda linguistik verbal. Dengan demikian mahasiswa yang memiliki kecerdasan ganda visual spasial lebih baik dibandingkan dengan mahasiswa yang memiliki kecerdasan linguistik verbal.

3. Terdapat interaksi antara media pembelajaran CD Multimedia Interaktif dan kecerdasan ganda dalam mempengaruhi hasil belajar TIK. Untuk mahasiswa yang memiliki kecerdasan ganda visual spasial akan lebih efektif dalam meningkatkan hasil belajar TIK jika menggunakan media pembelajaran $\mathrm{CD}$ Multimedia Interaktif, sedangkan untuk mahasiswa yang memiliki kecerdasan ganda linguistik verbal lebih efektif dalam meningkatkan hasil belajar TIK jika dibelajarkan dnegan menggunakan media pembelajaran Modul.

\section{Saran}

Berdasarkan hasil penelitian, simpulan, dan keterbatasan penelitian, maka dikemukakan saran-saran sebagai berikut :

1. Penggunaan media pembelajaran yang sesuai dengan karakteristik peserta didik dalam proses pembelajaran di perkuliahan sangat mempengaruhi hasil belajar mahasiswa. Oleh sebab itu disarankan kepada dosen/pendidik dapat menggunakan media yang lebih variatif dalam menyampaikan materi pembalajaran mengingat proses pembelajaran di perkuliahan tidak hanya berpusat pada pendidik (teacher orientied) yang mewajabkan tatap muka. Proses pembelajaran di perkuliahan yang banyak berkembang saat ini adalah pembelajaran dengan sistem kelas jarak jauh dan juga elearning. Pembelajaran jenis ini harus didukung oleh ketersediaan media yang dapat mengaksesnya agar proses pembelajaran dapat berjalan sesuai dengan target yang ingin dicapai.

2. Untuk meningkatkan hasil belajar TIK mahasiswa yang memiliki kecerdasan ganda visual spasial dan kecerdasan ganda linguistik verbal, penggunaan media pembelajaran $\mathrm{CD}$ multimedia interaktif dan modul sangat tepat karna kedua media ini memiliki unsur yang dibutuhkan mahasiswa untuk lebih termotivasi dalam mendalami pembelajaran. Kombinasi antara unsur visual dan verbal akan menghasilkan pembelajaran yang lebih baik karena kedua unsur tersebut dapat membuat mahasiswa menyerap informasi pembelajaran secara lebih cepat dan baik. Jadi sebaiknya penggunaan kedua media pembelajaran tersebut dikombinasikan dalam proses pembelajaran dan digunakan pada kelas kedua kelas penelitian.

3. Diharapkan pada penelitian selanjutnya, instrumen kecerdasan ganda tidak hanya merujuk pada daftar ceklist saja. Tetapi lebih mengarah kepada tes yang dapat mengukur kecerdasan ganda secara detail sesuai dengan aspek pembentuk kecerdasan ganda tersebut. Disarankan kepada peneliti selanjutnya untuk mengkonsultasikan instrumen kecerdasan ganda tersebut dengan pakar psikologi agar kualitas dan kesesuaian instrumen tepat digunakan di Indonesia karena banyak instrumen yan telah baku di luar negeri namun belum tentu tepat digunakan di Indonesia.

\section{DAFTAR PUSTAKA}

Anderson, O. W, Krathwohl, D.R. (2001). A Taxonomy for learning, Teaching, and Assessing. New York : Addison Wesley Longman, Inc

Amstrong, T. (1999). Seven Kinds of Smart, Menemukan dan Meningkatkan Kecerdasan Anda Berdasarkan Teori 
Multiple Inteligence. Jakarta : Gramedia Pustaka Utama.

Ariani, N dkk. (2010). Pembelajaran Multimedia di Sekolah, Pedoman Pembelajaran Inspiratif, Konstruktif dan Prospektif. Jakarta : Prestasi Pustaka.

Arifin B.C. (2009). Step by Step Membuat Video Tutorial Menggunakan Camtasia Studio. Bandung : OASE MEDIA.

Arsyad, A. (2007). Media Pembelajaran. Jakarta : Raja Grafindo Persada

Beni , D. M. (2008) Keunggulan Multimedia. http://deskomers01.com/?p=187 diakses tanggal 11 April 2010.

Briggs, M. L. (1982). Learning Theories For Teachers. New York : Harper \& Row.

Bunda Lucy. (2009). Mendidik Sesuai dengan Minat dan Bakat Anak. Jakarta: Tangga Pustaka.

Campbell, L, dkk. (1996). Teaching \& Learning Trough Multiple Intelligence. United States of America: MediaLink Associates, Inc.

Campbell, D.T. Stanley, J.C. (1956). Experimental and Quasy Experimental Design For Research. USA: Rand Mc Nally \& Company Chicago.

Chatib, Munif. (2010). Sekolahnya Manusia : Sekolah Berbasis Multiple Inteligences di Indonesia. Bandung : Kaifa.

Darma, J. S., Shenia Ananda. (2009). Buku Pintar Menguasai Multimedia. Jakarta : Mediakita.

Degeng, N.S. (2000). Pedoman Penyusunan Bahan Ajar. Lembaga Pengembangan Pendidikan dan Pembelajaran (LP3). Universitas Negeri Malang.

Djaali dan Pudji Muljono. (2004). Pengukuran Dalam Bidang Pendidikan. Intramedia : Jakarta.

Djamarah, S.B dan Aswan Z. (2006). Strategi Belajar Mengajar. Jakarta : PT. Rineka Cipta.

Gagne, Robert M \& Driscoll, Marcy P. (1989). Essentials of Learning for Instruction. New Jersey : Prentice Hall

Harsanto, R. (2007). Pengelolaan Kelas yang Dinamis. Yokyakarta : Kanisius.

Hoerr, Thomas R. (2007). Buku Kerja Multiple Inteligence. Bandung: Mizan Media Utama.

Jasmine, J. (2007). Paduan Praktis Mengajar Berbasis Multiple Intelligences. Bandung : Penerbit Nuansa.
Jubilee Enterprise. (2008). Tehnik Membuat Video Tutorial dengan Camtasia Studio 5. Jakarta : Elex Media Komputindo.

Kusrianto, Adi. (2007). Pengantar Desain Komunikasi Visual. Yogyakarta : Penerbit Andi.

Lwin, May,dkk. (2008). Cara Mengembangkan Berbagai Komponen Kecerdasan. PT. IndeksSabri,

Munadi, Yudhi. (2008). Media Pembelajaran, Sebuah Pendekatan Baru. Jakarta : Gaung Persada Press.

Olivia, Femi. (2009). Visual Thinking. Jakarta : Elex Media Komputindo.

Prasetyo, Justinus Reza dkk. (2009). Multiply Your Multiple Intelligences. Yogyakarta : Penerbit Andi

Reigeluth, C. M. (1983). Instructional Design Theory of Models : An Overview of Their Current Status. London : Prentice Hall

Romiszwoski, AJ. (1981). Instructional Design System, Decision Making in Course Planning and Curriculum Design. London : Prentice Hall

Sabri, Ahmad. (2007). Strategi Belajar Mengajar \& Micro Teaching. Jakarta : Quantum Teaching.

Sadiman, Arif S, dkk. (2007). Media Pendidikan. Jakarta : Raja Grafindo

Sagala, Syaiful. (2007). Konsep dan Makna Pembelajaran. Bandung: Penerbit Alfabeta.

Sanjaya, Wina. (2008). Strategi Pembelajaran Berorientasi Standar Proses Pendidikan. Jakarta : Kencana Prenada Media Group.

Sudarman, Paryati. (2004). Belajar Efektif di Perpendidikan Tinggi. Bandung : Simbiosa Rekatama Media.

Suparno, Paul. (2004). Teori Inteligensi Ganda dan Aplikasinya di Sekolah. Yogyakarta: Kanisius

Wasita, Bambang. (2008). Teknologi Pembelajaran, landasan dan Aplikasinya. Jakarta : Rineka Cipta.

Wilkson, Gene L. (1984). Media Dalam Pembelajaran. Jakarta : Raja Wali. Dan diterbitkan oleh Pustekom Dan Dikbud.

Widodo, Chomsin S dan Jasmadi. (2008). Paduan Menyusun Bahan Ajar Berbasis Kompetensi. Jakarta : Elex Media Komputindo.

Uno, Hamzah B. (2009). Mengelola Kecerdasan Dalam Pembelajaran. Jakarta : Bumi Aksara. 

http://www.wikimu.com/News/ diakses 